\title{
Adiponectin levels and sleep deprivation in patients with endocrine metabolic disorders
}

\author{
Roseane Feitosa de Oliveira ${ }^{1}$ \\ Thiago Medeiros da Costa Daniele \\ Cristina Figueiredo Sampaio Façanha, \\ Adriana Costa e Forti ${ }^{1}$ \\ Pedro Felipe Carvalhedo de Bruin,2 \\ Veralice Meireles Sales de Bruin ${ }^{\mathbf{1 , 2}}$
}

1. School of Medicine, Universidade Federal do Ceará (UFC). Postgraduate Program in Medical Sciences, UFC, Fortaleza, CE, Brasil 2. Sleep Lab and Biological Rhythms, Universidade Federal do Ceará (UFC), Fortaleza, CE, Brasil

http://dx.doi.org/10.1590/1806-9282.64.12.1122

\section{SUMMARY}

BACKGROUND: Sleep abnormalities are frequent in patients with endocrine metabolic disorders (EMD) such as arterial hypertension, diabetes and obesity. Adiponectin is a peptide largely secreted by adipocytes and has various properties e.g. anti-inflammatory, antioxidant, antiatherogenic, pro-angiogenic, vasoprotective and insulin-sensitizing. Adiponectin inversely relates to body weight and when its concentration decreases, the resistin concentration increases resulting in greater insulin resistance.

OBJECTIVE: The objective of this study is to examine factors influencing adiponectin levels in a population with EMD.

METHODS: This was a cross-sectional evaluation of 332 patients (18 to $80 \mathrm{y}$ ) presenting arterial hypertension, pre-diabetes, diabetes, and/or obesity. Investigation included clinical evaluation of comorbidities, general blood tests and adiponectin measures (ELISA). Chronic sleep deprivation was determined if habitual sleep was $<6$ hours $>4$ days/week.

RESULTS: Arterial hypertension (78.5\%), type-2 diabetes (82.3\%), and overweight (45.0\%)/obesity (38.8\%) were frequent. Patients with type-2 diabetes tended to have more chronic sleep deprivation $(p=0.05)$. Adiponectin levels increased with age and were inversely correlated with sagittal abdominal diameter $(p=0.04)$ and fasting insulin $(p=0.001)$. Chronic sleep deprivation was associated with higher adiponectin concentration [OR=1.34; $\mathrm{Cl}=1.13-1.58 ; p<0.005]$ and this was maintained after adjustment for gender, age, body mass index, menopause, arterial hypertension, American Diabetes Association classification and physical exercise levels [OR=1.38; $\mathrm{Cl}=1.14-1.66: p=0.001]$.

CONCLUSION: In patients with EMD, adiponectin is influenced not only by obesity but also by age and sleep deprivation. The latter finding may be explained by a compensatory effect or a counter regulation to minimize the harmful effects of sleep deprivation.

KEYWORDS: Sleep deprivation. Diabetes. Hypertension. Adiponectin. Obesity.

\section{INTRODUCTION}

The frequent clustering of arterial hypertension, diabetes and obesity is potentially aggravated by factors such as old age, smoking, alcohol consumption, sedentary lifestyle, among others. Chronic sleep deprivation occurs in various endocrine-metabolic disorders further aggravating a cascade of harmful effects ${ }^{1,2}$.
A recent review suggests that sleep disturbance and long sleep duration, but not short sleep duration, are associated with increases in markers of systemic inflammation ${ }^{3}$. Evidence suggests that sleep deprivation induces harmful effects on metabolic abnormalities, in the hypothalamic-pituitary-adrenal axis, and

DATE OF SUBMISSION: 16-May-2018

DATE OF ACCEPTANCE: 27-May-2018

CORRESPONDING AUTHOR: Veralice Meireles Sales de Bruin

Faculdade de Medicina, Universidade Federal do Ceará

R. Cel Nunes de Melo, 1315, Fortaleza, CE, Brasil - CEP 60430-270

Fax: +55 85 3261-1712

E-mail: veralicebruin@gmail.com

roseane_feitosa@ig.com.br danielethiago@yahoo.com.br crisffacanha@hotmail.com adrianaforti@uol.com.br pedrobruin@gmail.com 
ultimately weight gain ${ }^{4}$, In fact, an explanation for the biological changes found in patients with short or long sleep duration remains obscure. For instance, in healthy adults, sleep deprivation is associated with cognitive, neurophysiologic and endocrine changes, despite increased regional brain activity. These apparently paradoxical findings may be explained by adaptive behaviour or a compensatory effect ${ }^{5}$.

The adipose tissue secretes several bioactive molecules, known as adipokines that are influential to whole-body homeostasis and serve as a measure of adipose tissue activity ${ }^{6}$. Adiponectin is the most abundant adipocytokine and has a regulatory effect on the metabolism of glucose and lipid ${ }^{7,8}$. High adiponectin levels have been associated with positive cardiovascular benefits; whereas low values of adiponectin are connected to obesity, metabolic syndrome, type 2 diabetes and dyslipidaemia9. Previously, female diabetic showed higher adiponectin levels than male indicating $a$ gender effect ${ }^{10}$. Furthermore, higher adiponectin levels are inversely related to body weight and to insulin resistance $^{10}$. All this evidence indicates that a complex set of variables influence adiponectin concentration.

The objective of the present study is to investigate factors influencing adiponectin expression in a population with endocrine-metabolic disorders.

\section{METHODS}

\section{Study design and patients}

This is a cross sectional evaluation of 332 patients with endocrine-metabolic disorders. We consecutively recruited patients from an outpatient clinic at Centro Integrado de Diabetes e Hipertensão (CIDH) in Fortaleza, Brazil. Initially, 400 subjects from the central database were examined. Sixty-eight were excluded due to difficulty of posterior examination $(\mathrm{N}=34)$, severe associated comorbidities $(\mathrm{N}=23)$ or refusal to participate in the study $(\mathrm{N}=11)$. Three-hundred and thirty-two of them attended the eligible criteria for the desired analyses. Plasma adiponectin levels were obtained in a subsample of 120 patients. The study involved individuals of both genders, aged from 18 to 80 years old, with a Body Mass Index (BMI) from 18.5-45.0 kg/ $\mathrm{m}^{2}$. All patients underwent clinical evaluation, investigation of comorbid disorders and blood tests. None had severe heart disease, renal insufficiency, stroke, dementia, severe depression, gastrointestinal and/or liver dysfunction or previous diagnosis of cancer. In this study, patients with type 1 diabetes and/or on use of insulin or glucocorticoids were not included. The local Research Ethics Committee (HUWC-CEP 031-04-09) approved the protocol and all included patients provided written informed consent.

\section{Assessments}

Three previously trained health workers assessed demographic and clinical information using a face-toface interview. Endocrine-metabolic disorders were investigated. Arterial hypertension was defined as a systolic blood pressure $\geq 140 \mathrm{~mm} \mathrm{Hg}$, diastolic blood pressure $\geq 90 \mathrm{~mm} \mathrm{Hg}$, and/or current use of antihypertensive medications ${ }^{11}$. American Diabetic Association (ADA) classification rated patients as normal, with glucose intolerance or diabetes. The presence of a fastening $\geq 126 \mathrm{mg} / \mathrm{dl}$, post-prandial glucose concentration $\geq 200 \mathrm{mg} / \mathrm{dl}$, or diabetes symptoms and a plasmatic glucose concentration (last mealtime independent) $\geq 200 \mathrm{mg} / \mathrm{dl}$ defined diabetes ${ }^{12}$. Intermediate plasma glucose levels situated between those considered normal and those considered diabetic characterized impaired glucose tolerance. A fasting blood glucose level of above $6.0 \mathrm{mmol} / \mathrm{L}$ or a blood glucose level of over $7.8 \mathrm{mmol} / \mathrm{L} 2$ hours after consuming $75 \mathrm{~g}$ of glucose established impaired glucose tolerance. Overweight was considered if Body Mass Index (BMI) $\geq 25 \mathrm{~kg} / \mathrm{m}^{2}$ and obesity if $\mathrm{BMI} \geq 30 \mathrm{~kg} / \mathrm{m}^{2}$. Hyperlipidaemia was defined as an alteration in lipid profile, in which the Low Density Cholesterol (LDL) $\geq 100 \mathrm{mg} / \mathrm{dl}$, High Density Cholesterol (HDL) $<40 \mathrm{mg} /$ $\mathrm{dl}$ and/or triglycerides $>150 \mathrm{mg} / \mathrm{dl}^{13}$. Chart review confirmed the clinical information.

Questionnaires investigated sleep duration, physical exercise and comorbidities. Patients were questioned about how many hours of sleep they usually get during the week and during the weekend. Less than six hours of sleep per day occurring at least four days per week defined the presence of chronic sleep deprivation. Less than 30 minutes of exercise per day and/ or the absence of heavy physical exertion at home or at work, namely cleaning, hand washing clothes or other defined physical inactivity.

\section{Biochemical analyses}

Blood sampling and laboratory measurements were obtained in all patients. Samples were taken for biochemical investigations in blood collection tubes (Vacutainer - Vacuum II ${ }^{\circledR}$ ). Blood was drawn from an antecubital vein with the participants in a sitting po- 
sition and was collected between 7:00 am and 9:30 AM, without stasis; the serum was separated after centrifugation for 10 minutes and stored at -70 degrees Celsius for the analyses. Adiponectin levels were determined by ELISA using commercial kits (Kit Assay Designs Cortisol ELISA, Michigan, USA ${ }^{\circledR}$ ).

\section{Statistical analysis}

Descriptive statistics are presented as mean (standard deviation), range and frequency (percentage values). Fisher exact tests for categorical variables, Mann-Whitney $U$ test for continuous variables and Student's t test for normally distributed data with equal variances compared between groups. Patients were grouped as having or not $<6$ hours of sleep. Adiponectin and variables were correlated (Pearson test). A logistic regression analysis model examined the associations of variables with reduced hours of sleep $(<6 \mathrm{~h})$. In this model, gender, age, menopause, BMI, arterial hypertension, ADA classification and physical exercise level were all included. In this regression model all variables were included in a single step (enter). Statistical analysis used SPSS for Windows, version 21.0 and $p<0.05$ was required for the statistical significance.

\section{RESULTS}

The majority of patients had arterial hypertension (78.5\%), type 2 diabetes (82.3\%), and overweight (45.0\%) or obesity (38.8\%). Menopause affected half of the women (50.6\%). Patients with arterial hypertension frequently had type 2 diabetes $(83.4 \%)$, were older $(60.1 \pm 10.6$ vs $51.2 \pm 11.2, \mathrm{p}<0.005)$ and had higher BMI $\left(29.8 \pm 5.3 \mathrm{~kg} / \mathrm{m}^{2}\right.$ vs $\left.27.9 \pm 4.1 \mathrm{~kg} / \mathrm{m}^{2}, \mathrm{p}=0.007\right)$. Table 1 depicts general characteristics of patients in the entire group of patients and according to the presence of chronic insufficient sleep ( $<6 \mathrm{~h})$. Reduced sleep time tended to be more frequent in patients with reduced glucose tolerance (ADA classification, $\mathrm{p}=0.05$ ).

In this population, adiponectin levels were inversely to sagittal abdominal diameter (Pearson Exact Test: $r=-0.176, p=0.04$ ) and to fasting insulin levels (Pearson Exact Test: $\mathrm{r}=-0.226, \mathrm{p}=0.008$ ) (Figure 1A and 1B). Adiponectin levels were higher in patients with chronic sleep deprivation (4.2 \pm 2.7$)$ than in those without $(2.5 \pm 2.0$ ) (Students' $t$ test, $p=0.001$ ) (Figure 2). Older age [OR=1.02; $\mathrm{CI}=1.00-1.05 ; \mathrm{p}=0.03]$ and increased adiponectin levels [OR=1.34; CI=1.13-1.58; $\mathrm{p}<0.005$ ] were associated with reduced hours of sleep $(<6 \mathrm{~h})$.
Adiponectin concentration remained associated with sleep deprivation after adjustment for gender, age, menopause, BMI, arterial hypertension, ADA classification and physical exercise level $[\mathrm{OR}=1.38$; $\mathrm{CI}=1.14$ 1.66: $\mathrm{p}=0.001$ ] (Table 2).

\section{DISCUSSION}

This study shows that in patients with endocrine metabolic disorders, adiponectin levels are higher in older patients and are negatively related to sagittal abdominal diameter and fasting insulin. These findings are in agreement with previous reports demonstrating higher adiponectin levels with increasing age in both genders, regardless of the presence of obesity ${ }^{14}$. The role of increased adiponectin with increasing age is unclear. Kizer et al. suggest that age-related homeostatic dysregulation explains high adiponectin levels over time in long-lived adults. These higher values have been associated with greater physical disability and mortality ${ }^{15}$.

Previous studies confirm that adiposity is negatively related to adiponectin levels ${ }^{16,17}$. In this work, only sagittal abdominal diameter was inversely related to adiponectin concentration indicating that this measure is a reliable predictor of visceral adiposity ${ }^{\mathbf{1 8} 19}$. Similar to our findings, high fasting insulin was associated with lower levels of adiponectin. More precisely, increased resistin has been associated with lower adiponectin ${ }^{20}$. Our findings confirm that low values of adiponectin are connected to adiposity and high fasting insulin.

Presently, sleep deprivation was independently associated with elevated adiponectin levels. We hypothesize that the latter findings can be explained by a compensatory mechanism to limit the harmful effects of sleep deprivation. In agreement, a counter-regulatory effect mitigating further damage was previously suggested ${ }^{21}$. To the best of our knowledge, to date, no study reported a relationship between chronic sleep deprivation and adiponectin levels in a population with endocrine-metabolic disorder. Previous studies relating adiponectin levels with chronic sleep alterations show controversial results. In healthy young volunteers, Robertson et al. described no changes of adiponectin levels after three weeks of reduced daily sleep duration ${ }^{21}$. Simpson et al. reported differential effects according to gender and ethnicity ${ }^{22}$. Taheri et al. described, in a population of recruited volunteers, no change in adiponectin levels 
TABLE 1: CLINICAL CHARACTERISTICS OF PATIENTS ACCORDING TO THE PRESENCE/ABSENCE OF SIX HOURS OF SLEEP

\begin{tabular}{|c|c|c|c|c|}
\hline Variables & $\begin{array}{l}\text { All cases } \\
\mathrm{N}=322\end{array}$ & $\begin{array}{l}\geq 6 \mathrm{~h} / \text { sleep } \\
\mathrm{N}=243\end{array}$ & $\begin{array}{l}<6 h \text { sleep } \\
\mathrm{N}=79\end{array}$ & p-value \\
\hline $\begin{array}{l}\text { Male/Female, N/ } \\
(\%)\end{array}$ & $\begin{array}{l}131 / 191 \\
(40.7) /(59.3)\end{array}$ & $\begin{array}{l}103 / 140 \\
(42.3)\end{array}$ & $\begin{array}{l}28 / 51 \\
(35.4)\end{array}$ & b 0.29 \\
\hline $\begin{array}{l}\text { Age (y), Range } \\
\text { Mean (SD) }\end{array}$ & $\begin{array}{l}29-80 \\
58.2(11.3)\end{array}$ & $\begin{array}{l}29-80 \\
57.5(11.1)\end{array}$ & $\begin{array}{l}31-79 \\
60.6(11.2)\end{array}$ & a 0.36 \\
\hline Menopause N, \% & $162(50.6)$ & $113(80.7)$ & $46(90.1)$ & b 0.15 \\
\hline Arterial Hypertension Yes/No & $253(78.5)$ & $186(77.8)$ & $65(82.3)$ & b 0.43 \\
\hline $\begin{array}{l}\text { (ADA) (Normal, Red. Tolerance, Diabetes) } \\
\text { N/\% }\end{array}$ & $\begin{array}{l}22 / 35 / 265 \\
(6.8 / 10.9 / 82.3)\end{array}$ & $\begin{array}{l}18 / 21 / 204 \\
(7.5 / 8.6 / 83.9)\end{array}$ & $\begin{array}{l}4 / 14 / 61 \\
(5.1 / 17.7 / 77.2)\end{array}$ & b 0.05 \\
\hline $\begin{array}{l}\text { Smoker (never, previous, current) } \\
\text { N/\% }\end{array}$ & $\begin{array}{l}210 / 76 / 36 \\
(65.2 / 23.6 / 11.1)\end{array}$ & $\begin{array}{l}157 / 26 / 58 \\
(65.2 / 10.8 / 24.0)\end{array}$ & $\begin{array}{l}51 / 10 / 18 \\
(64.6 / 12.6 / 22.8)\end{array}$ & b 0.86 \\
\hline Alcoholism N, \% & $28(8.7)$ & $24(10.0)$ & $4(5.0)$ & b 0.42 \\
\hline $\begin{array}{l}\text { BMI Range. Mean } \\
\text { (SD) }\end{array}$ & $\begin{array}{l}19.1-50.5 \\
29.4(5.1)\end{array}$ & $\begin{array}{l}19.1-50.5 \\
29.3(5.2)\end{array}$ & $\begin{array}{l}21.8-42.9 \\
29.8(4.8)\end{array}$ & a 0.39 \\
\hline $\begin{array}{l}\text { Hip-Waist Variation. Mean } \\
\text { (SD) }\end{array}$ & $\begin{array}{l}0.84-1.77 \\
1.05(0.1)\end{array}$ & $\begin{array}{l}0.84-1.75 \\
1.05(0.10)\end{array}$ & $\begin{array}{l}0.89-1.77 \\
1.05(0.11)\end{array}$ & a 0.87 \\
\hline $\begin{array}{l}\text { Abdominal circumference }(\mathrm{cm}) \text { Range Mean } \\
(\mathrm{SD})\end{array}$ & $\begin{array}{l}59-148 \\
103.9(10.9)\end{array}$ & $\begin{array}{l}59-148 \\
103.5(11.2)\end{array}$ & $\begin{array}{l}87-135 \\
105.2(9.9)\end{array}$ & a 0.22 \\
\hline $\begin{array}{l}\text { Neck circumference }(\mathrm{cm}) \text { Range Mean } \\
\text { (SD) }\end{array}$ & $\begin{array}{l}24-50 \\
38.5(3.8)\end{array}$ & $\begin{array}{l}24-50 \\
38.6(3.8)\end{array}$ & $\begin{array}{l}30.5-48 \\
38.4(3.9)\end{array}$ & a 0.73 \\
\hline $\begin{array}{l}\text { Thigh circumference }(\mathrm{cm}) \text { Range Mean } \\
\text { (SD) }\end{array}$ & $\begin{array}{l}34-103 \\
50.8(8.1)\end{array}$ & $\begin{array}{l}34-79 \\
50.5(7.3)\end{array}$ & $\begin{array}{l}37-103 \\
51.5(10.1)\end{array}$ & a 0.34 \\
\hline $\begin{array}{l}\text { Arterial systolic pressure Range Mean } \\
\text { (SD) }\end{array}$ & $\begin{array}{l}98-220 \\
138(21.0)\end{array}$ & $\begin{array}{l}98-220 \\
137.5(21.0)\end{array}$ & $\begin{array}{l}100-204 \\
140.1(21.4) \\
\end{array}$ & a 0.35 \\
\hline $\begin{array}{l}\text { Arterial diastolic pressure Range Mean } \\
\text { (SD) }\end{array}$ & $\begin{array}{l}60-120 \\
81.6(10.7)\end{array}$ & $\begin{array}{l}60-120 \\
81.3(10.6)\end{array}$ & $\begin{array}{l}60-106 \\
82.8(11.0)\end{array}$ & a 0.29 \\
\hline Physical activity (sedentary/mild/moderate \& intense) & $179 / 80 / 62$ & $139 / 57 / 45$ & $40 / 23 / 16$ & b 0.49 \\
\hline Sun exposure (score) & $\begin{array}{l}0-56 \\
13.9(12.2)\end{array}$ & $\begin{array}{l}0-56 \\
13.7(12.6)\end{array}$ & $\begin{array}{l}0-42 \\
14.2(10.6)\end{array}$ & c 0.75 \\
\hline
\end{tabular}

Abbreviations: ADA= American Diabetic Association; BMI= Body Mass Index; SD= Standard Deviation a Student's t-test; b Fisher exact test; c Mann-Whitney test

FIGURE 1: ADIPONECTIN LEVELS WERE INVERSE TO SAGITTAL ABDOMINAL DIAMETER (A) AND TO FASTING INSULIN LEVELS (B).
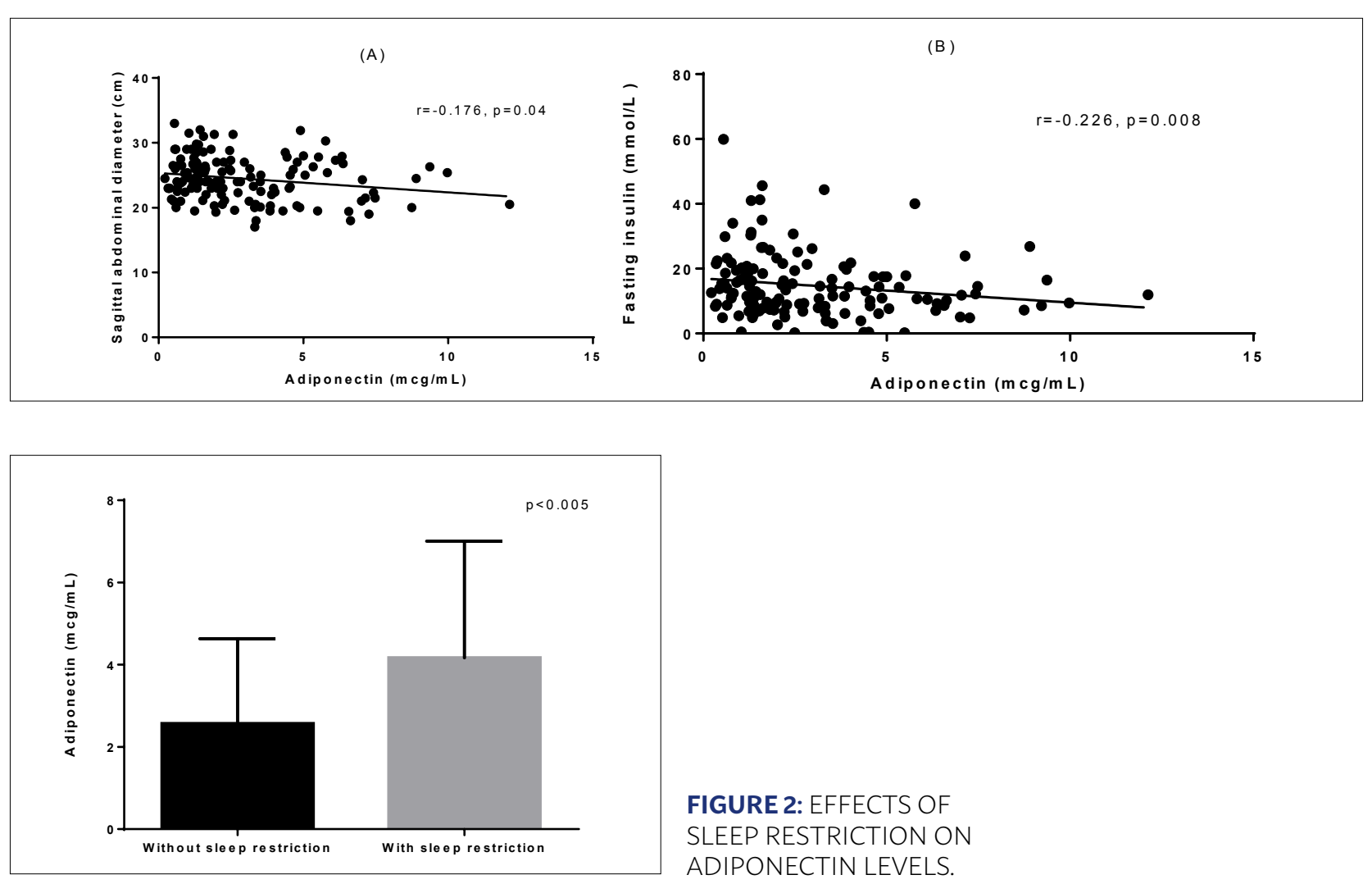

FIGURE 2: EFFECTS OF

SLEEP RESTRICTION ON ADIPONECTIN LEVELS. 
TABLE 2: LOGISTIC REGRESSION ANALYSIS OF FACTORS

ASSOCIATED WITH REDUCED HOURS OF SLEEP $(<6 \mathrm{H})$

\begin{tabular}{|c|c|c|c|}
\hline Variable & Exp B & $\mathrm{Cl}$ & p-value \\
\hline Gender & 1.33 & [0.78-2.26] & 0.28 \\
\hline Age & 1.02 & [1.00-1.05] & $0.03^{*}$ \\
\hline Menopause & 1.49 & [0.89-2.49] & 0.12 \\
\hline Arterial hypertension & 0.75 & {$[0.39-1.45]$} & 0.40 \\
\hline ADA Classification & 0.87 & {$[0.56-1.34]$} & 0.53 \\
\hline $\mathrm{BMI}$ & 1.02 & [0.97-1.07] & 0.39 \\
\hline Waist-Hip & 1.20 & [0.11-13.1] & 0.87 \\
\hline Neck circumference & 0.98 & [0.92-1.05] & 0.73 \\
\hline Vitamin D & 1.00 & [0.97-1.03] & 0.65 \\
\hline Adiponectin & 1.34 & {$[1.13-1.58]$} & $<0.005^{\star \star}$ \\
\hline Sun exposure & 1.00 & {$[0.98-1.02]$} & 0.75 \\
\hline Physical activity & 1.14 & {$[0.83-1.57]$} & 0.39 \\
\hline Alcoholism & 0.86 & {$[0.60-1.21]$} & 0.39 \\
\hline Smoker & 0.99 & [0.73-1.33] & 0.95 \\
\hline \multicolumn{4}{|c|}{$\begin{array}{c}\text { Multivariate analysis (adjustments for gender, age, menopause, BMI, arterial hype } \\
\text { tension, ADA classification, and physical exercise level, enter model) }\end{array}$} \\
\hline Adiponectin & 1.457 & {$[1.17-1.81]$} & 0.001 \\
\hline
\end{tabular}

in relation to chronic sleep deprivation ${ }^{24}$. In obese subjects, plasma low adiponectin level was associated with obstructive sleep apnea ${ }^{25}$. In partial agreement with the latter study, low adiponectin levels, increased levels of inflammatory markers, and atherogenic lipid profiles were found in association with obstructive sleep apnoea in hypertensive patients ${ }^{26}$. In opposition to the previous studies, an increase of adiponectin levels was associated with sleep apnea ${ }^{25,27}$ Furthermore, adiponectin also shows a circadian pattern ${ }^{28}$. Regrettably, in the present work, sleep apnoea and circadian rhythm were not investigated. Together, all this evidence indicates that adiponectin levels are influenced by a range of factors.

In this study, patients with diabetes tended to have more sleep deprivation. Both, short and long sleep duration, and poor glucose control are reported in patients with type 2 diabetes ${ }^{29,30}$. In our study, no gender effect was found ${ }^{23}$. In opposition to our findings, higher levels of adiponectin were found in women $^{31,32}$. In hypertensive patients, gender and renal function influenced adiponectin levels ${ }^{21}$.

Interestingly, in this population, adiponectin measures did not correlate with anthropometric measures or to Gamma-glutamyltransferase (GGT) measures. Hsieh et al. showed that low serum adiponectin level may precipitate hepatic steatosis in patients with type 2 diabetes ${ }^{33}$. Another data supported a role for low circulating adiponectin in the pathogenesis of non-alcoholic fat liver disorder ${ }^{34}$.

Limitations must to be acknowledged. In this study, chronic sleep deprivation was evaluated only by questionnaires and objective sleep measures were not recorded. Nonetheless, the strength of the present study is that it is the first to examine adiponectin levels in relation to sleep deprivation in patients with multiple endocrine-metabolic disorders.

In summary, we show that chronic sleep deprivation affects approximately $1 / 4$ of patients with endocrine-metabolic disorders. Patients with type 2 diabetes tended to have more chronic sleep deprivation. Adiponectin levels increased with age and higher values were independently associated with chronic sleep deprivation. Increased sagittal abdominal diameter and fasting insulin levels were negatively correlated with adiponectin levels. These findings reinforce the concept that low adiponectin levels have an obnoxious effect, and multiple factors and counter-regulatory effects may influence adiponectin levels.

\section{Acknowledgements}

We wish to thank MCT/CNPq for supporting this study.

\section{Declaration of Interest}

The authors report no conflicts of interest. The authors alone are responsible for the content and writing of the paper. 


\section{RESUMO}

INTRODUÇÃO: Problemas de sono são frequentes em pacientes com distúrbios endócrino-metabólicos (DEM), como hipertensão arterial, diabetes e obesidade. A adiponectina é um peptídeo segregado por adipócitos e apresenta diversas propriedades, como por exemplo, anti-inflamatória, antioxidante, antiaterogênica, pró-angiogênica e vasoprotetora. A adiponectina relaciona-se inversamente com o peso corporal.

\section{OBJETIVO: Examinar os fatores que influenciam os níveis de adiponectina em uma população com DEM.}

MÉTODOS: Trata-se de uma avaliação transversal com 332 pacientes (18 a 80 anos) apresentando hipertensão arterial, pré-diabetes, diabetes elou obesidade. A investigação incluiu avaliação clínica de comorbidades, exames de sangue e medidas de adiponectina (Elisa). A restrição crônica do sono foi determinada com o sono habitual <6 horas $>4$ dias/semana.

RESULTADOS: Doenças como hipertensão arterial (78,5\%), diabetes tipo $2(82,3 \%)$ e sobrepeso $(45,0 \%)$ /obesidade (38,8\%) foram frequentes. Pacientes com diabetes tipo 2 apresentaram uma tendência na restrição crônica do sono $(p=0,05)$. Os níveis de adiponectina aumentaram com a idade e foram inversamente correlacionados com o diâmetro abdominal sagital $(p=0,04)$ e com a insulina em jejum $(p=0,001)$. A restrição crônica do sono foi associada à maior concentração de adiponectina $[O R=1,34 ; C l=1,13-1,58 ; p<0,005]$ e isso foi mantido após ajuste por gênero, idade, índice de massa corporal, menopausa, hipertensão arterial, classificação dos níveis da American Diabetes Association e exercício físico [OR=1,38; Cl=1,14-1,66: $p=0,001]$.

CONCLUSÕES: Em pacientes COM DEM, a adiponectina é influenciada não apenas pela obesidade, mas também pela idade e pela restrição de sono. O último achado pode ser explicado por um efeito compensatório ou por um regulamento contrário para minimizar os efeitos nocivos da restrição do sono.

PALAVRAS-CHAVE: Restrição do sono. Diabetes. Hipertensão. Adiponectina. Obesidade.

\section{REFERENCES}

1. Brum MC, Filho FF, Schnorr CC, Bottega GB, Rodrigues TC. Shift work and its association with metabolic disorders. Diabetology \& metabolic syndrome. 2015;7:45

2. Broussard JL, Chapotot F, Abraham V, Day A, Delebecque F, Whitmore $H R$, Tasali E. Sleep restriction increases free fatty acids in healthy men. Diabetologia. 2015;58:791-798

3. Irwin MR, Olmstead R, Carroll JE. Sleep disturbance, sleep duration, and inflammation: A systematic review and meta-analysis of cohort studies and experimental sleep deprivation. Biological psychiatry. 2016;80:40-52

4. Spiegel K, Knutson K, Leproult R, Tasali E, Van Cauter E. Sleep loss: A novel risk factor for insulin resistance and type 2 diabetes. Journal of applied physiology (Bethesda, Md. : 1985). 2005;99:2008-2019

5. Klumpers UM, Veltman DI, van Tol MI, Kloet RW, Boellaard R, Lammertsma AA, Hoogendijk WJ. Neurophysiological effects of sleep deprivation in healthy adults, a pilot study. PloS one. 2015;10:e0116906

6. Check $J$. The interrelationship of sleep, biologic clocks, neurotransmitters, gonadotropins and pubertal development. Clinical and experimental obstetrics \& gynecology. 2013;40:7-14

7. Faraj M, Lu HL, Cianflone K. Diabetes, lipids, and adipocyte secretagogues. Biochemistry and cell biology = Biochimie et biologie cellulaire. 2004;82:170-190

8. Tao C, Sifuentes A, Holland WL. Regulation of glucose and lipid homeostasis by adiponectin: Effects on hepatocytes, pancreatic beta cells and adipocytes. Best practice \& research. Clinical endocrinology \& metabolism. 2014;28:43-58

9. Davis SK, Gebreab SY, Xu R, Riestra P, Khan RJ, Sumner AE, Hickson D, Bidulescu A. Association of adiponectin with type 2 diabetes and hypertension in african american men and women: The jackson heart study. BMC cardiovascular disorders. 2015;15:13

10. Aleidi S, Issa A, Bustanji H, Khalil M, Bustanji Y. Adiponectin serum levels correlate with insulin resistance in type 2 diabetic patients. Saudi pharmaceutical journal : SPJ : the official publication of the Saudi Pharmaceutical Society. 2015;23:250-256

11. Alpert $B$, McCrindle B, Daniels S, Dennison B, Hayman L, Jacobson M, Mahoney L, Rocchini A, Steinberger J, Urbina E, Williams R. Recommendations for blood pressure measurement in human and experimental animals; part 1: Blood pressure measurement in humans. Hypertension (Dallas, Tex. : 1979). 2006;48:e3; author reply e5

12. Sacks DB, Arnold M, Bakris GL, Bruns DE, Horvath AR, Kirkman MS, Lernmark A, Metzger BE, Nathan DM. Guidelines and recommendations for laboratory analysis in the diagnosis and management of diabetes mellitus. Clinical chemistry. 2011;57:e1-e47
13. Fletcher B, Berra K, Ades P, Braun LT, Burke LE, Durstine JL, Fair JM, Fletcher GF, Goff D, Hayman LL, Hiatt WR, Miller NH, Krauss R, Kris-Etherton P, Stone N, Wilterdink J, Winston M. Managing abnormal blood lipids: A collaborative approach. Circulation. 2005;112:3184-3209

14. Schautz B, Later W, Heller M, Peters A, Muller MJ, Bosy-Westphal A. Impact of age on leptin and adiponectin independent of adiposity. The British journal of nutrition. 2012;108:363-370

15. Kizer JR, Arnold AM, Strotmeyer ES, Ives DG, Cushman M, Ding J, Kritchevsky SB, Chaves PH, Hirsch CH, Newman AB. Change in circulating adiponectin in advanced old age: Determinants and impact on physical function and mortality. The cardiovascular health study all stars study. The journals of gerontology. Series A, Biological sciences and medical sciences. 2010;65:1208-1214

16. Laughlin GA, Barrett-Connor E, May S. Sex-specific determinants of serum adiponectin in older adults: The role of endogenous sex hormones. International journal of obesity (2005). 2007;31:457-465

17. Cohen SS, Gammon MD, Signorello LB, North KE, Lange EM, Fowke JH, Hargreaves MK, Cai Q, Zheng W, Blot WJ, Matthews CE. Serum adiponectin in relation to body mass index and other correlates in black and white women. Annals of epidemiology. 2011;21:86-94

18. Pajunen P, Rissanen $H$, Laaksonen MA, Heliovaara M, Reunanen A, Knekt P. Sagittal abdominal diameter as a new predictor for incident diabetes. Diabetes care. 2013;36:283-288

19. Hoenig MR. Mri sagittal abdominal diameter is a stronger predictor of metabolic syndrome than visceral fat area or waist circumference in a high-risk vascular cohort. Vascular health and risk management. 2010;6:629-633

20. Siddiqui K, George TP. Serum adipokines (adiponectin and resistin) correlation in developing gestational diabetes mellitus: Pilot study. 2017:1-5

21. Mallamaci F, Zoccali C, Cuzzola F, Tripepi G, Cutrupi S, Parlongo S, Tanaka S, Ouchi N, Kihara S, Funahashi T, Matsuzawa Y. Adiponectin in essential hypertension. Journal of nephrology. 2002;15:507-511

22. Robertson MD, Russell-Jones D, Umpleby AM, Dijk DJ. Effects of three weeks of mild sleep restriction implemented in the home environment on multiple metabolic and endocrine markers in healthy young men. Metabolism: clinical and experimental. 2013;62:204-211

23. Simpson NS, Banks S, Arroyo S, Dinges DF. Effects of sleep restriction on adiponectin levels in healthy men and women. Physiology \& behavior. 2010;101:693-698

24. Taheri S, Lin L, Austin D, Young T, Mignot E. Short sleep duration is associated with reduced leptin, elevated ghrelin, and increased body mass index. PLoS medicine. 2004;1:e62 
25. Zeng F, Wang X, Hu W, Wang L. Association of adiponectin level and obstructive sleep apnea prevalence in obese subjects. Medicine. 2017;96:e7784

26. Abdel-Fadeil MR, Abedelhaffez AS, Makhlouf HA, Al Qirshi GA. Obstructive sleep apnea: Influence of hypertension on adiponectin, inflammatory markers and dyslipidemia. Pathophysiology: the official journal of the International Society for Pathophysiology. 2017

27. Wolk R, Svatikova A, Nelson CA, Gami AS, Govender K, Winnicki M, Somers VK. Plasma levels of adiponectin, a novel adipocyte-derived hormone, in sleep apnea. Obesity research. 2005;13:186-190

28. Gomez-Abellan P, Gomez-Santos C, Madrid JA, Milagro FI, Campion J, Martinez JA, Ordovas JM, Garaulet M. Circadian expression of adiponectin and its receptors in human adipose tissue. Endocrinology. 2010;151:115-122

29. Alnaji A, Law GR, Scott EM. The role of sleep duration in diabetes and glucose control. The Proceedings of the Nutrition Society. 2016;75:512-520

30. Daniele TM, Bruin VM, Oliveira DS, Pompeu CM, Forti AC. Associa- tions among physical activity, comorbidities, depressive symptoms and health-related quality of life in type 2 diabetes. Arq Bras Endocrinol Metabol. 2013;57:44-50

31. Kern PA, Di Gregorio GB, Lu T, Rassouli N, Ranganathan G. Adiponectin expression from human adipose tissue: Relation to obesity, insulin resistance, and tumor necrosis factor-alpha expression. Diabetes. 2003:52:1779-1785

32. Bottner A, Kratzsch |, Muller G, Kapellen TM, Bluher S, Keller E, Bluher M, Kiess W. Gender differences of adiponectin levels develop during the progression of puberty and are related to serum androgen levels. The Journal of clinical endocrinology and metabolism. 2004;89:4053-4061

33. Hsieh C), Wang PW, Hu TH. Association of adiponectin gene polymorphism with nonalcoholic fatty liver disease in taiwanese patients with type 2 diabetes. PloS one. 2015;10:e0127521

34. Pagano C, Soardo G, Esposito W, Fallo F, Basan L, Donnini D, Federspil G, Sechi LA, Vettor R. Plasma adiponectin is decreased in nonalcoholic fatty liver disease. European journal of endocrinology. 2005;152:113-118 